\title{
Forecasting Biomass Loss and Carbon Released to the Atmosphere as a Result of Habitat Conversion of Eastern Selous-Niassa TFCA
}

\author{
Adili Y. Zella ${ }^{1}$, Josephat Saria ${ }^{2}$, Yohana Lawi ${ }^{3}$ \\ ${ }^{1}$ Department of Economic Studies, The Mwalimu Nyerere Memorial Academy (MNMA)-Zanzibar, P.O Box 307, Zanzibar, \\ Tanzania. \\ ${ }^{2,3}$ Department of Environmental Studies, Faculty of Science, Technology and Environmental Studies, Open University of \\ Tanzania, P.O Box 23409, Dar es Salaam, Tanzania.
}

\begin{abstract}
Terrestrial climate change predictions use various models that are based on atmospheric parameters combined with projected carbon emission scenarios. Increased levels of carbon emissions into the atmosphere are accelerated by human activities and are the main reason of climate change $(C C)$. CC threatens networks of protected areas (PAs) and forced many species out of PAs. Unfenced PAs gives species opportunity to migrate from one PA to another or other unprotected areas to sustain their climatic niche. Many PAs in SADC countries including transfrontier conservation areas (TFCA) are unfenced; hence, connectivity of PAs uses corridors. However, many of these corridors are unprotected and advocacies adaptation of reserved fauna and flora under CC. This paper explains the less known amount of biomass loss and carbon released to the atmosphere as result of habitat conversion of eastern corridor of Selous - Niassa TFCA which connecting the two PAs of Tanzania and Mozambique. Specifically, the study predicts amount of biomass loss, amount of carbon released to the atmosphere and amount of conservation profit disposed as a result of habitat conversion from 2015 to 2035. Existing data on spatial and temporal changes in land use and land cover (LULC) of eastern corridor of Selous - Niassa TFCA from 1986 - 2016 was analysed and used to forecast LULC from 2015 to 2035 by using CA-Markov model. The forecasted LULC from 2015 to 2035 was analysed to get intended results. The results revealed that, an average amount of 29559.8 tons of biomass (above ground + below ground + deadwood) loss annually from 2015 to 2035. Consequently, average amount of 40217.2 tons of carbon (above ground + below ground + deadwood) released to the atmosphere annually from 2015 to 2035 equivalent to US\$160868.6 per annum if REDD+ implemented. The study concludes that, there is a need to include virgin corridors into core PAs
\end{abstract}

network or formulation of sustainable conservation strategies that will consider climatic niche of both flora and fauna without compromising livelihoods of corridor dwellers.

Keywords- Habitat conversion, Climate change mitigation and adaptation, Biomass, Carbon

\section{INTRODUCTION}

\subsection{Background information}

Terrestrial climate change predictions use various models that are based on atmospheric parameters combined with projected carbon emission scenarios. However, uncertainty is associated with these predictions, and at least 16 different models are in use (Nature Conservancy, 2009; Malimbwi et al., 2016). These global models have high uncertainties as emission scenarios vary depending on future energy use choice of different communities; and those models are suitable in predicting changes in temperature rather than precipitation. These global models have advantage of being, in principle, applicable anywhere. However, due to great variation in climatic and edaphic factors, such models can yield large error locally. Thus, a model developed on data from a smaller region, will within that region give more accurate estimates (Malimbwi et al., 2016; Kulindwa et al., 2016; Lobora et al., 2017).

Increased levels of carbon emissions into the atmosphere accelerated by human activities are the main reason of climate change. Terrestrial carbon sinks include soils, trees and other vegetation soaks up at least half of annual greenhouse gases emissions from fossil fuels resulting to slow down of climate -warming gases in our atmosphere (Kulindwa et al., 2016). Carbon dioxide $\left(\mathrm{CO}_{2}\right)$ sequestration is one of great role of forests and woodlands ecosystem, other roles include protection of watersheds, soil conservation, conservation of biodiversity, sustaining 
cultural values, climatic amelioration and eco-tourism. Despite all the valuable and invaluable goods and services provided by forests, there are high rates of deforestation and forest degradation in developing countries (Malimbwiet al., 2016). For instance, Tanzania is among the developing country in East Africa where the aforementioned scenario accelerating deterioration of over 10,000 plant species, hundreds of which are nationally endemic. Among plant and animal species in Tanzania, 724 are identified as "Threatened" in the World Conservation Union (IUCN) Red List with 276 species classified as "Endangered" (IUCN, 2013). Some of these forests and woodlands are within protected areas (PAs) rich of biodiversity (fauna and flora) of different categories and others unprotected areas termed as public good (general land). These scenarios necessitate development of allometric models for measuring biomass and volume of different forest and woodland species of Tanzania (URT, 2015).

All PAs in Tanzania are unfenced. Wildlife uses that opportunity to migrate from one PA to another or other areas for climate change adaptation. One of the unprotected areas for adaptation are wildlife/biodiversity corridors which connect two or more PAs within the country or transfrontier conservation areas (TFCA). Connectivity of PAs through corridors advocacy adaptation of reserved fauna and flora under climate change. The protection of corridor biodiversity relies on the ability to assess hot spots, quantify and predict spatial and temporal trends of key species, maintain a natural disturbance regime, and limit harmful human activities (Stohlgren et al., 1999).

\subsection{Problem statement}

Classification and management of networks of protected areas (PA) is pre-requisite for sustainable biodiversity conservation. However, these networks are commonly considered static because areas that have been classified as PAs almost never declassified (Mascia and Pailler, 2011; Malimbwi et al., 2016). Habitat loss, fragmentation, overhunting and resource depletion are among drivers of populations decline which PAs safeguarding species from those shocks(UNEP 1992); consequently, climate change forced many species out of PAs (Kulindwa et al, 2016; Lobora et al., 2017). Certainly, models project that several PAs will lose suitable habitats for species of high conservation concern ( Hole et al., 2009; Kharouba and Kerr, 2010; Ara_ujo et al., 2011; Virkkala et al., 2013; Malimbwi et al., 2016; Kulindwa et al, 2016; Lobora et al., 2017). To address this challenge, researchers and conservation bodies recognize that new conservation areas will need to be designated in future (Hannah \& Salm 2003;
Ara_ujo 2009b; Lobora et al., 2017). This scenario faces many transfrontier conservation areas (TFCAs) in Africa including Selous - Niassa TFCA.

Selous - Niassa TFCA is connected by the corridor between Selous Game Reserve (Tanzania) and Niassa National Reserve (Mozambique) making an area of $154000 \mathrm{~km}^{2}$ of natural miombo woodlands ecosystem. The TFCA consist a network of PAs of various categories of protection; an area of $110,000 \mathrm{~km}^{2}$ of this ecosystem is presently under conservation (Baldus and Hahn, 2009). The corridor connecting these two PAs to form TFCA is unprotected ecosystem. However, areas adjacent to TFCA PAs formulated WMAs (wildlife management areas) so as to involve community in conservation of wildlife outside PAs. Though, the effects of climate change and variability suggests that, WMAs is not enough strategy as species use the corridor for migration and others adapted in the corridor due to its suitability for their climatic niche.

Therefore, the increasing concerns over the impacts of climate change necessitate the inclusion of new PAs categories to increase connectivity between PAs through wildlife/biodiversity/habitat corridors. This study intended to forecast amount of biomass loss, carbon released to the atmosphere, and conservation profit to be disposed as a result of habitat conversion of eastern corridor of SelousNiassa TFCA from 2015 to 2035

\subsection{Objectives}

\subsubsection{Main objective}

The main objective of this study was to predict amount of biomass and carbon released to the atmosphere as a result of habitat conversion of eastern corridor of Selous-Niassa TFCA

\subsubsection{Specific objectives}

Specifically the study intends to:

(i) predict amount of biomass loss of eastern corridor of Selous-Niassa TFCA from 2015 to 2035

(ii) predict amount of carbon released to the atmosphere as a result of habitat conversion of eastern corridor of Selous-Niassa TFCA from 2015 to 2035

(iii) predict amount of conservation profit disposed as a result of habitat conversion of eastern corridor of Selous-Niassa TFCA from 2015 to 2035

\section{MATERIALS AND METHODS}

\subsection{Materials}

\subsubsection{Description of the Study Area}


The study was carried out in eastern Selous-Niassa TFCA with an area of 1, 462, 560 hectares called Selous-Niassa wildlife corridor (SNWC) which extends across southern Tanzania into northern Mozambique (Figure 1). Administratively passes in Liwale, Nachingwea,Masasi, and Nanyumbu Districts. Migration of elephants, buffalos and zebras has been observed (Pesambili, 2003; Ntongani et al., 2007). Two migratory routes have been identified as follows:

(i) From Selous through Nahimba, Nakalonji, Mbondo, Kilimarondo, Matekwe and Kipindimbi proposed game reserve (GR) in Nachingwea District and then via Msanjesi, Mkumbalu, Sengenya, Nangomba and Nanyumbu in Nanyumbu District to LukwikaLumesule GR and then crosses Ruvuma River to the Niassa GR.

(ii) From Selous to Kiegei, Namatumu, Kilimarondo in Nachingwea then along Mbangala and Lumesule rivers to Mchenjeuka and Mitanga in the Lukwika-Lumesule GR, from where they cross the Ruvuma River to the Niassa Reserve.

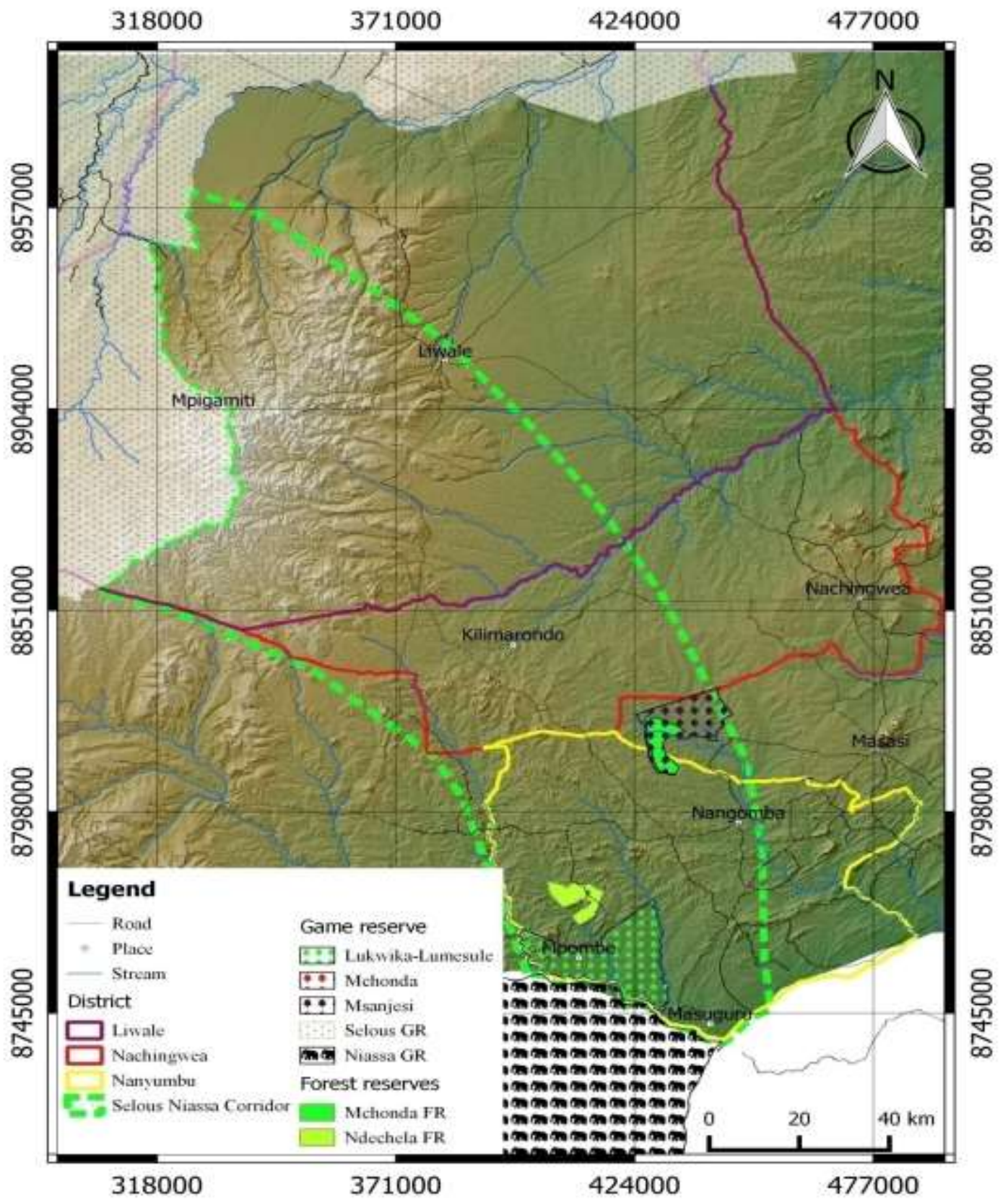

Fig.1: The Map of the study area 
These routes forms SNWC called Selous-Masasi corridor includes the Msanjesi (2,125 ha) and the LukwikaLumesule $(44,420$ ha) GRs in Masasi and Nanyumbu Districts respectively; wildlife management areas (WMAs) bordering Selous, Msanjesi and Lukwika-Lumesule game reserves (MAGINGO WMA, NDONDA and MCHIMALU proposed WMAs respectively) which are within Liwale, Nachingwea/Masasi and Nanyumbu Districts respectively.

\subsection{Methods}

Prediction of land use and land cover change of eastern corridor of Selous - Niassa TFCA from 2015 to 2035 using Markov Chain Analysis and Cellular Automata Analysis, jointly called CA-Markov was employed as shown in Figure 2 and Table 1.

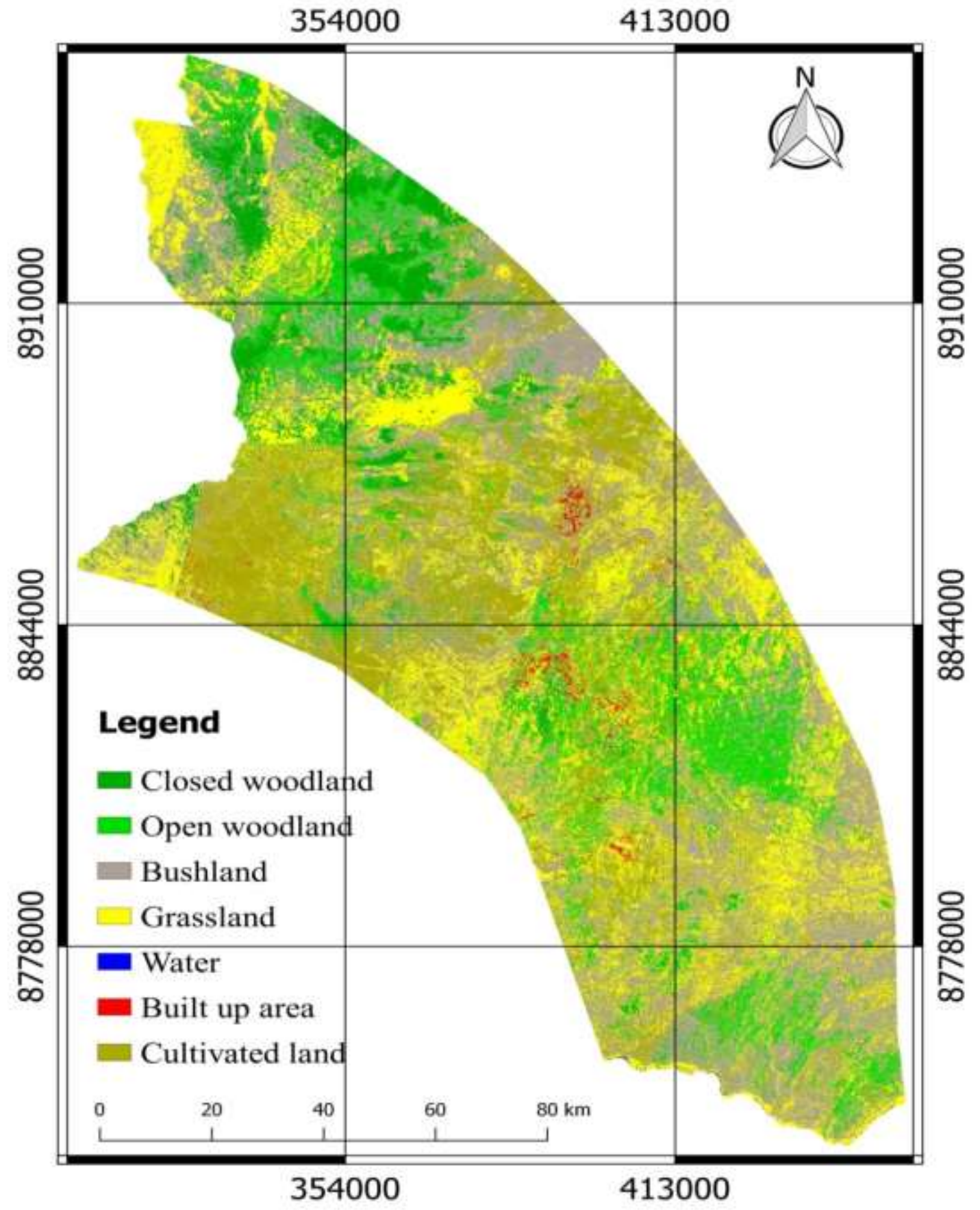

Fig.3: Projected Land use/cover map for eastern corridor of Selous-Niassa TFCA for 2035 


\begin{tabular}{l|cccc}
\multicolumn{5}{c}{ Table.2: Land use/cover area distribution in 2035 } \\
\hline \multirow{2}{*}{ LULC } & \multicolumn{3}{|c}{$\mathbf{2 0 1 5}$} & $\mathbf{2 0 3 5}$ \\
\cline { 2 - 5 } & $\mathbf{( H a )}$ & $\mathbf{( \% )}$ & $\mathbf{( H a )}$ & $\mathbf{( \% )}$ \\
\hline Closed woodland & 89923 & 6.15 & 81981 & 5.61 \\
Open woodland & 220217 & 15.06 & 211690 & 14.47 \\
Bushland & 480269 & 32.84 & 411950 & 28.17 \\
Grassland & 394461 & 26.97 & 411272 & 28.12 \\
Water & 646 & 0.04 & 242 & 0.02 \\
Built up area & 8851 & 0.61 & 12749 & 0.87 \\
Cultivated land & 268193 & 18.34 & 332676 & 22.75 \\
\hline TOTAL & $\mathbf{1 4 6 2 5 6 0}$ & $\mathbf{1 0 0}$ & $\mathbf{1 4 6 2 5 6 0}$ & $\mathbf{1 0 0}$ \\
\hline
\end{tabular}

\subsubsection{Data analysis}

To predict amount of biomass loss of eastern corridor of Selous-Niassa TFCA from 2015 to 2035

2.2.1.1 Biomass Stocks

\subsection{Living Biomass Stocks}

Tanzania forest Carbon can be estimated in three pools namely AGB (above ground biomass), BGB (below ground biomass) and DW (dead wood) (URT, 2015). BGB was estimated as a fraction of AGB. AGB and BGB were estimated as follows: (i) AGB (tonnes/ha) $=$ Tree stem volume $\left(\mathrm{m}^{3} / \mathrm{ha}\right) *$ wood density/1000; and

(ii) $\mathrm{BGB}$ (tonnes/ha) $=\mathrm{AGB} * 0.25$ (as default), or root to shoot ratios.

URT (2015) uses conversion factors into programmed NAFORMA analysis system by tree species or species groups to provide standards in each terrestrial ecosystem of Tanzania as shown in Table 3.

Table.3: Living tree stemwood biomass by primary vegetation type

\begin{tabular}{l|ccccccc}
\hline Primary Vegetation Type & CWD & OWD & BS & GL & WTR & CL & BLT \\
\hline Aboveground Biomass (t/ha) & 59.5 & 27.7 & 11.0 & 2.9 & 4.6 & 5.9 & 2.9 \\
Belowground Biomass (t/ha) & 18.2 & 9.5 & 4.4 & 1.1 & 1.7 & 2.1 & 1.1 \\
\hline
\end{tabular}

CWD $=$ Closed woodland, OWD = Open woodland, BS = Bushland, GL = Grassland, WTR $=$ Water, $\mathbf{C L}=$ Cultivated land and BLT $=$ Built Up area

\subsection{Deadwood Biomass Stocks}

Dead wood (DW) biomass is estimated from the volume computed using Smalian formula multiplied by wood density of $619 \mathrm{~kg} / \mathrm{m}^{3}$ (Chidumayo, 2012 cited by URT, 2015). URT (2015) through NAFORMA reveals the dead wood Biomass of Tanzania (Table 4) is relatively low since most dead wood in accessible areas is collected as fuelwood. As woodlands are generally more accessible than forests, collection of deadwood for fuelwood from these areas is easier. The relatively high volume of dead wood in water is assumed to be because dead trees lying in areas with water / wetlands are difficult to access and decay slowly and because they are wet and therefore unattractive for fuelwood.

Table.4: Dead wood biomass by primary vegetation type

\begin{tabular}{l|ccccccc}
\hline $\begin{array}{l}\text { Primary Vegetation } \\
\text { Type }\end{array}$ & CWD & OWD & BS & GL & WTR & CL & BLT \\
\hline Biomass (t/ha) & 4.87 & 1.82 & 0.73 & 0.35 & 1.31 & 0.91 & 0.22 \\
\hline
\end{tabular}

CWD = Closed woodland, OWD = Open woodland, BS = Bushland, GL = Grassland, WTR = Water, CL = Cultivated land and BLT = Built Up area

To predict amount of carbon released to the atmosphere as a result of habitat conversion of eastern corridor of Selous-Niassa TFCA from 2015 to 2035

\subsubsection{Carbon Stocks}


According to URT (2015), carbon in terrestrial ecosystems of Tanzania can be computed as follows:

Carbon $($ tonnes $/$ ha $)=$ Biomass $* 0.47$

Living tree stemwood and dead wood carbon (t/ha) by primary vegetation type are illustrated in Table $5 \& 6$.

Table.5: Living tree stemwood Carbon (Aboveground + Belowground) by primary vegetation type

\begin{tabular}{l|ccccccc}
\hline $\begin{array}{l}\text { Primary Vegetation } \\
\text { Type }\end{array}$ & CWD & OWD & BS & GL & WTR & CL & BLT \\
\hline Carbon (t/ha) & 36.5 & 17.5 & 7.2 & 1.8 & 3.0 & 3.8 & 1.9 \\
\hline
\end{tabular}

CWD = Closed woodland, OWD = Open woodland, BS = Bushland, GL = Grassland, WTR = Water, $\mathbf{C L}=$ Cultivated land and BLT = Built Up area

Table.6: Dead wood Carbon by primary vegetation type

\begin{tabular}{l|ccccccc}
\hline $\begin{array}{l}\text { Primary Vegetation } \\
\text { Type }\end{array}$ & CWD & OWD & BS & GL & WTR & CL & BLT \\
\hline Carbon (t/ha) & 2.39 & 0.89 & 0.36 & 0.17 & 0.64 & 0.45 & 0.11 \\
\hline
\end{tabular}

CWD = Closed woodland, OWD = Open woodland, BS = Bushland, GL = Grassland, WTR = Water, $\mathbf{C L}=$ Cultivated land and BLT $=$ Built Up area

To predict amount of conservation profit disposed as a result of habitat conversion of eastern corridor of Selous-Niassa TFCA from 2015 to 2035

The study adopted from Jenkins (2014), Malimbwi et al. (2016), Kulindwa et al. (2016) and Lobora et al. (2017) emphasized different carbon market per ton depending on different countries and continents, but the standard carbon market suggested is US\$ 4 per ton if REDD+ is implemented. This was used to predict amount of conservation profit that will be disposed from 2015 to 2035 as a result of habitat conversion of eastern corridor of Selous-Niassa TFCA.

\section{RESULTS AND DISCUSSION}

\subsection{Amount of biomass that will be loss in eastern} corridor of Selous-Niassa TFCA from 2015 to 2035

The results in Table 7 and Table 8 revealed that, $124.5 \%$ of biomass will be loss in woodland, bushland and water; while, $24.5 \%$ of biomass will be stored by other vegetation type as a result of habitat conversion of eastern corridor of Selous-Niassa TFCA . Bushland alone will loss $67.7 \%$ of biomass, followed by woodlands (56.7\%). This implies that, average amount of 36801.95 tons of biomass (above ground + below ground + deadwood) from woodlands; bushland; and water will be loss annually from 2015 to 2035. Moreover, average amount of 7242.19 tons of biomass (above ground + below ground + deadwood) from other vegetation type will be stored annually from 2015 to 2035 . The results shows that, the natural vegetation will be degraded and new tree species will take (under succession) place. The degradation will impacts negatively ecosystem services offered to wildlife residing or using the area for migration or adapting to climatic change. The degraded area will be converted to bushland, cultivated land and built up area due to increase of human population, livestock, and dependence of corridor dwellers on existing natural resources in the ecosystem for their livelihoods. Thereof, the average total annual loss will be 29559.76 tons of biomass (above ground + below ground + deadwood) in all vegetation type from 2015 to 2035 . These results necessitated the emergence of new management strategies of the area which will assure the survival of wildlife without compromising livelihoods of corridor dwellers. The existing formulation of wildlife management areas (WMAs) of Liwale (MAGINGO), Nachingwea (NDONDA) and Nanyumbu (MCHIMALU) districts relies only adjacently to core PAs of Selous, Msanjesi and Lukwika-Lumesule game reserves, and forgetting other areas which are crucial to wildlife, using their living habitat and migration trails. 
Table.7: Amount of living tree stemwood biomass (Aboveground + Belowground) loss of eastern corridor Selous-Niassa TFCA from 2015 to 2035

\begin{tabular}{l|ccccc}
\hline $\begin{array}{c}\text { Primary Vegetation } \\
\text { Type }\end{array}$ & $\begin{array}{c}\text { Total area } \\
\text { converted } \\
\text { (ha) }\end{array}$ & $\begin{array}{c}\text { Above ground } \\
\text { biomass loss } \\
(\mathbf{t} / \mathbf{h a})\end{array}$ & $\begin{array}{c}\text { Below ground } \\
\text { biomass loss } \\
(\mathbf{t} / \mathbf{h a})\end{array}$ & $\begin{array}{c}\text { Total Biomass loss } \\
(\mathbf{t})\end{array}$ & $\begin{array}{c}\text { Biomass loss } \\
(\boldsymbol{\%})\end{array}$ \\
\hline Closed woodland & 7942 & 4.87 & 18.2 & 183221.9 & 35.91 \\
Open woodland & 8527 & 1.82 & 9.5 & 96525.64 & 18.92 \\
Bushland & 68319 & 0.73 & 4.4 & 350476.5 & 68.69 \\
Grassland & -16811 & 0.35 & 1.1 & -24376 & -4.78 \\
Water & 404 & 1.31 & 1.7 & 1216.04 & 0.24 \\
Cultivated land & -3898 & 0.91 & 2.1 & -11733 & -2.3 \\
Built up area & -64483 & 0.22 & 1.1 & -85117.6 & -16.68 \\
\hline Total & & & & $\mathbf{5 1 0 2 1 3 . 6}$ & $\mathbf{1 0 0 . 0 0}$ \\
\hline
\end{tabular}

Table.8: Amount of dead wood biomass loss of eastern corridor of Selous-Niassa TFCA from 2015 to 2035

\begin{tabular}{l|cccc}
\hline \multicolumn{1}{c|}{$\begin{array}{c}\text { Primary Vegetation } \\
\text { Type }\end{array}$} & $\begin{array}{c}\text { Total area } \\
\text { converted (ha) }\end{array}$ & $\begin{array}{c}\text { Biomass loss } \\
(\mathbf{t} / \mathbf{h a})\end{array}$ & $\begin{array}{c}\text { Total Biomass loss } \\
(\mathbf{t})\end{array}$ & $\begin{array}{c}\text { Biomass loss } \\
(\boldsymbol{\%})\end{array}$ \\
\hline Closed woodland & 7942 & 4.87 & 38677.54 & 47.76 \\
Open woodland & 8527 & 1.82 & 15519.14 & 19.16 \\
Bushland & 68319 & 0.73 & 49872.87 & 61.59 \\
Grassland & -16811 & 0.35 & -5883.85 & -7.27 \\
Water & 404 & 1.31 & 529.24 & 0.65 \\
Cultivated land & -3898 & 0.91 & -3547.18 & -4.38 \\
Built up area & -64483 & 0.22 & -14186.3 & -17.52 \\
\hline Total & & & $\mathbf{8 0 9 8 1 . 5}$ & $\mathbf{1 0 0 . 0 0}$ \\
\hline
\end{tabular}

\subsection{Amount of Carbon released to the atmosphere as a result of habitat conversion of eastern corridor of Selous-Niassa TFCA from 2015 to 2035}

The results in Table 9 and Table 10 revealed that, $122.29 \%$ of carbon will released to the atmosphere from in woodland, bushland and water; while, $22.9 \%$ of carbon will be stored by other vegetation type as a result of habitat conversion of eastern corridor of Selous-Niassa TFCA. Bushland alone will loss $64.1 \%$ (516491.6 tons) of carbon, followed by woodlands $57.89 \%$ (465675.9 tons). This implies that, average amount of 49181.91tons of carbon (above ground + below ground + deadwood) from woodlands; bushland; and water will be loss annually from 2015 to 2035. Moreover, average amount of 8964.75 tons of carbons (above ground + below ground + deadwood) from other vegetation type will be stored annually from 2015 to 2035 . This is something that we can never stay quiet; and the need to act urgently is unquestionable. Thus, the need for sustainable utilization and management of natural resources in the area is vital. Nevertheless, the average total annual loss will be 40217.16 tons of Carbon (above ground + below ground + deadwood) from 2015 to 2035. Since, climate change is a result of increasing greenhouse gases in the atmosphere, there are must be strategies to reverse the situation. If, we decide to include the area into core PA network, we must revise the current participatory management strategies which insist on formulation of Wildlife Management Areas (WMAs) but forgetting that those WMAs are only adjacent to core PAs which in other scenarios doesn't fit. Thus, the need to formulate other management strategies that will include all areas in the corridor which has wildlife climatic niche; economical and ecological importance for corridor dwellers is unavoidable. 
Table.9: Amount of living tree stemwood Carbon (Aboveground + Belowground) that will be released to the atmosphere as a result of habitat conversion of eastern corridor of Selous-Niassa TFCA from 2015 to 2035

\begin{tabular}{l|cccc}
\hline $\begin{array}{c}\text { Primary Vegetation } \\
\text { Type }\end{array}$ & $\begin{array}{c}\text { Total area converted } \\
\text { (ha) }\end{array}$ & $\begin{array}{c}\text { Carbon loss } \\
(\mathbf{t} / \mathbf{h a})\end{array}$ & Total Carbon loss (t) & $\begin{array}{c}\text { Share } \\
(\boldsymbol{\%})\end{array}$ \\
\hline Closed woodland & 7942 & 36.5 & 289883 & 37.91 \\
Open woodland & 8527 & 17.5 & 149222.5 & 19.52 \\
Bushland & 68319 & 7.2 & 491896.8 & 64.33 \\
Grassland & -16811 & 1.8 & -30259.8 & -3.96 \\
Water & 404 & 3.0 & 1212 & 0.16 \\
Cultivated land & -3898 & 3.8 & -14812.4 & -1.94 \\
Built up area & -64483 & 1.9 & -122518 & -16.02 \\
\hline Total & & & $\mathbf{7 6 4 6 2 4 . 4}$ & $\mathbf{1 0 0}$ \\
\hline
\end{tabular}

Table.10: Amount of dead wood Carbon that will be loss in eastern corridor of Selous-Niassa TFCA from 2015 to 2035

\begin{tabular}{l|cccc}
\hline $\begin{array}{c}\text { Primary Vegetation } \\
\text { Type }\end{array}$ & $\begin{array}{c}\text { Total area } \\
\text { converted (ha) }\end{array}$ & $\begin{array}{c}\text { Carbon loss } \\
(\mathbf{t} / \mathbf{h a})\end{array}$ & $\begin{array}{c}\text { Total Carbon loss } \\
(\mathbf{t})\end{array}$ & $\begin{array}{c}\text { Share } \\
(\mathbf{\%})\end{array}$ \\
\hline Closed woodland & 7942 & 2.39 & 18981.38 & 47.79 \\
Open woodland & 8527 & 0.89 & 7589.03 & 19.11 \\
Bushland & 68319 & 0.36 & 24594.84 & 61.92 \\
Grassland & -16811 & 0.17 & -2857.87 & -7.19 \\
Water & 404 & 0.64 & 258.56 & 0.65 \\
Cultivated land & -3898 & 0.45 & -1754.1 & -4.42 \\
Built up area & -64483 & 0.11 & -7093.13 & -17.86 \\
\hline Total & \multicolumn{4}{|c}{} \\
\hline
\end{tabular}

\subsection{Amount of conservation profit that will be disposed} as a result of habitat conversion of eastern corridor of Selous-Niassa TFCA from 2015 to 2035

Results in Table 11 revealed that, eastern corridor of Selous - Niassa TFCA will loss an average amount of US\$ 160868.6 of carbon trade annually from 2015 to 2035 due to habitat conversion of the area. Woodlands, bushland and water pioneered degradation on which they will loss an annual average of US\$ 196727.6 from 2015 to 2035 . It seems that the area have potential hard wood species which Table.12: Amount of conservation profit disposed as a result of habitat conversion of eastern Selous-Niassa TFCA from 2015 to

\begin{tabular}{l|ccc}
\multicolumn{5}{c}{2035} \\
\multicolumn{1}{c|}{$\begin{array}{c}\text { Primary Vegetation } \\
\text { Type }\end{array}$} & $\begin{array}{c}\text { Total Carbon loss } \\
(\mathbf{t})\end{array}$ & $\begin{array}{c}\text { Amount of money loss } \\
\text { (US\$) }\end{array}$ & Share (\%) \\
\hline Closed woodland & 308864.4 & 1235458 & 38.4 \\
Open woodland & 156811.5 & 627246.1 & 19.5 \\
Bushland & 516491.6 & 2065967 & 64.21 \\
Grassland & -33117.7 & -132471 & -4.12 \\
Water & 1470.56 & 5882.24 & 0.18 \\
Cultivated land & -16566.5 & -66266 & -2.06 \\
Built up area & -129611 & -518443 & -16.11 \\
\hline Total & $\mathbf{8 0 4 3 4 3 . 1}$ & $\mathbf{3 2 1 7 3 7 2}$ & $\mathbf{1 0 0}$ \\
\hline
\end{tabular}

are regarded as commercial rewarding but environmental destructive by corridor dwellers. Sustainable utilization of natural resources in the area is of important priority. Thus, we need to integrate community in management of the area by combined PFM (Participatory Forest Management), JFM (Joint Forest Management) and WMA (Wildlife Management Areas) and having one entity which will be integral and community-centered in decision making on corridor management. 
IV. CONCLUSION AND RECOMMENDATIONS

This study predicted amount of biomass loss and carbon released to the atmosphere as a result of habitat conversion of eastern corridor of Selous - Niassa TFCA from 2015 to 2035. The findings have revealed that, the study area will undergo notable biomass loss of 591195.1 tons due to socio-economic activities performed by corridor dwellers. Also amount of carbon released to the atmosphere of 804343.1 tons can contribute much to climate change and climate variability. The amount of conservation profit disposed of annual average of USD 160868.6 seems to offset amount of benefit received by corridor dwellers from their destructive activities if adopted REDD+ strategies. The scenario necessitates formulation of sustainable management strategies that will emphasis on species adaptability in the corridor ecosystem in regard to their climatic niche without compromising livelihoods of corridor dwellers. Furthermore, adequately adapting conservation policies to climate change requires a paradigm shift. Specifically, planners need to adopt a long-term view and accept that under budgetary constraints the release of PAs areas that become redundant at some point in time might be required if new conservation areas (wildlife corridors) are to be designated to meet conservation targets.

\section{REFERENCES}

[1] Ara_ujo, M.B. (2009b) Protected areas and climate change in Europe: A discussion paper prepared for the 29th meeting of the Standing Committee. Convention on the Conservation of European Wildlife and Natural Habitats, Strasbourg, 23-26 November 2009, pp. 29.

[2] Araújo, M. B., Alagador, D., Cabeza, M., NoguésBravo, D. and Thuiller, W. (2011), Climate change threatens European conservation areas. Ecology Letters, 14: 484-492. doi:10.1111/j.14610248.2011.01610.x

[3] Baldus, R.D. and Hahn, R. (2009). The Selous Niassa Wildlife Corridor in Tanzania: Biodiversity Conservation from the Grassroots. Practical Experiences and Lessons from Integrating Local Communities into Trans-boundary Natural Resources Management. Joint publication of FAO and CIC. Budapest. 48pp.

[4] Chidumayo, E. N. (2012). Assessment of Existing Models for Biomass and Volume Calculations for Zambia (58 p). Report Prepared for FAO-Zambia Integrated Land Use Assessment (ILUA) Phase II Project.

[5] Hannah, L. \&Salm, R. (2003) Protected areas and climate change. Climate Change and Biodiversity:
Synergistic Impacts (eds L. Hannah \& T. Hole, D.G., Willis, S.G., Pain, D.J., Fishpool, L.D., Butchart, S.H.M., Collingham, Y.C., Rahbek, C. \& Huntley, B. (2009) Projected impacts of climate change on a continent-wide protected area network. Ecology Letters, 12, 420-431.

[6] IUCN (2013). IUCN Red list of threatened species. Version 2013.01. IUCN, Gland. http://www.iucnredlist..org/.

[7] Jenkins, C.N., and Joppa, L. (2009). Expansion of the global terrestrial protected area system. Biological Conservation, $142 \quad$ (10), 2166-2174. doi:10.1016/j.biocon. 2009. 04.016

[8] Kharouba, H.M. \& Kerr, J.T. (2010). Just passing through: global change and the conservation of biodiversity in protected areas. Biological Conservation, 143, 1094-1101.

[9] Kundilwa, K.A., Silayo, D., Zahabu, E., Lokina, R., Hella, J., Hepelwa, A., Shirima, D., Macrice, S., and Kalonga, S. (2016). Lessons and implications for REDD+ implementation: Experiences from Tanzania. CCIAM-SUA, Morogoro, Tanzania. 372pp.

[10] Lobora, A., Nahonyo, C., Munishi, L., Caro, T., Foley, C., and Beale, C. (2017): Modelling habitat conversion in miombo woodlands: insights from Tanzania, Journal of Land Use Science, DOI: 10.1080/1747423X.2017.1331271

[11] Malimbwi, R.E., Eid, T., and Chamsama, S.A.O. (2016). Allometric tree biomass and volume models in Tanzania, Sokoine University, Morogoro. 129pp.

[12] Mascia, M.B. and Pailler, S. (2011). Protected area downgrading, downsizing, and degazettement (PADDD) and its conservation implications. Conservation Letters, 4, 9-20.

[13] The Nature Conservancy. 2009. Protected Area Management Planning. A Target-based approach. A practitioner's guidance. Unpublished draft February 2009.

[14] Ntongani, W.A., Munishi, P.K.T. and Mbilinyi, B.P. (2007). Land use/cover change and socio-economic factors influencing land cover dynamics in the SelousNiassa wildlife corridor Nachingwea District Tanzania. Proceedings of the sixth TAWIRI scientific conference. Dec, 2007.

[15] Pesambili, A. (2003). Wildlife resources of LukwikaLumesule and Msanjesi Game Reserves. WWF-TPO. $12 \mathrm{pp}$.

[16] Stohlgren, T. J., Binkley, D., Chong, G. W., Kalkhan, M. A., Schell, L. D., Bull, K. A., Otsuki, Y., Newman, G., Bashkin, M. and Son, Y. (1999), Exotic Plant 
Species Invade Hot Spots Of Native Plant Diversity. Ecological Monographs, 69: 25-46. doi:10.1890/00129615(1999)069[0025:EPSIHS]2.0.CO;2

[17] UNEP (1992). Report of the Sixth Meeting of the Conference of the Parties to the Convention on Biological Diversity United Nations Environmental Programme, The Hague.

[18] United Republic of Tanzania (URT), (2015). National Forest Resources Monitoring and Assessment of Tanzania Mainland. Ministry of Natural Resources and Tourism, Dar es Salaam. 106pp.

[19] Virkkala, R., Heikkinen, R., Fronzek, S., Kujala, H. \&Leikola, N. (2013) Does the protected area network preserve bird species of conservation concern in a rapidly changing climate? Biodiversity and Conservation, 22, 459-482. 